\title{
Transformasi Spasial Hunian Pada Eks-Backpacker Enclaves Studi Kasus: Jalan Jaksa, Jakarta Pusat
}

\author{
Vika Haristianti1, Wiwik Dwi Pratiwi² \\ ${ }^{1}$ Fakultas Industri Kreatif, Universitas Telkom \\ ${ }^{2}$ Sekolah Arsitektur, Perencanaan, dan Pengembangan Kebijakan, Institut Teknologi Bandung \\ haristiantivika@telkomuniversity.ac.id
}

\begin{abstract}
ABSTRAK
Penelitian ini bertujuan untuk mengidentifikasi sejauh mana transformasi spasial terjadi pada hunian di Jalan Jaksa yang dikenal sebagai daerah eks-backpacker enclaves akibat adanya konsep supply dan demand. Fungsi ruang, fasad bangunan serta koridor pada hunian merupakan variable yang dinilai. Penelitian ini menggunakan metode kualitatif. Pengumpulan data dilakukan dengan cara observasi lapangan, wawancara dan juga telaah literatur. Adapun pengambilan sampel dilakukan dengan menggunakan tipe non-random atau probability sampel. Hasil analisis menunjukan dari 26 jumlah sampel terdapat 12 sampel bangunan/hunian (46.1\%) yang mengalami installation, berarti sifat bangunannya adaptif, lima sampel bangunan/hunian (19.2\%) mengalami insertion, keadaan bangunan dinilai cukup adaptif serta sembilan bangunan/hunian (34\%) mengalami intervention berarti keadaan bangunan tidak adaptif. Selain itu kategori perubahan terbanyak adalah perubahan hunian menjadi gedung bertingkat, penginapan, dan mixed use building .
\end{abstract}

Kata kunci: Transformasi, hunian, backpacker enclaves, adaptive reuse

\section{ABSTRACT}

This study aims to discover the extent of spatial transformation in residential areas on Jalan Jaksa, known as the ex-backpacker enclaves due to the concept of supply and demand. Spatial function, building facades, and corridors in residentials are the assessed variables. This study uses a qualitative method. Data collection is done by field observations, interviews, and literature review. The sampling method is using a nonrandom type or probability sample. The results of the analysis showed that from 26 samples there were 12 building/residential samples (46.1\%) that underwent installation, meaning that the building characteristics were adaptive, five buildings/ residential samples (19.2\%) had insertion, meaning that the building was considered to be quite adaptive, and nine buildings/ residential samples (34\%) experiencing intervention, which means the building is not adaptive. In addition, the most changing category is the transformation in housing into multi-story buildings, lodging, and mixed-use buildings.

Keywords: Transformation, housing, backpacker enclaves, adaptive reuse

\section{Pendahuluan}

Jalan Jaksa merupakan sebuah jalan yang berada di Kelurahan Kebon Sirih, Kecamatan Menteng, Jakarta Pusat. Adapun yang dimaksud sebagai eks-backpacker enclaves dalam judul penelitian ini adalah jalan tersebut. Backpacker enclaves sendiri dapat diibaratkan sebagai sebuah kantung, tempat bertemunya berbagai macam kebudayaan (Westerhausen \& Macbeth, 2003). Tempat ini memungkinkan backpacker bersosialisasi dengan sesamanya setelah mereka menjelajahi wilayah asing, memperkuat jiwa mereka dan berkontribusi membentuk identitas individu dan kelompok (Vogt, 1976 dalam Haristianti, 2016). Jika dilihat dari keberadaannya, Jalan Jaksa dinilai sebagai sebuah 
kawasan istimewa dan memiliki sejarah yang cukup panjang. Bermula ketika terjadi fenomena masuknya backpacker ke Jalan Jaksa setelah kemerdekaan, tepatnya di akhir tahun 1960-an. Saat itu adalah awal mula Jalan Jaksa mulai dikenal secara internasional di antara para wisatawan mancanegara dari segmen wisata ransel. Fenomena tersebut menyebabkan warga sekitar melihat peluang bisnis yang positif, sehingga satu persatu warga mulai merubah fungsi hunian nya menjadi sarana akomodasi bagi backpacker. Perubahan terus terjadi hingga jalan ini mencapai puncak kejayaan pada periode 1990an.

Maju dan mundurnya objek dan daya tarik wisata Jalan Jaksa sangat dipengaruhi oleh situasi perekonomian Indonesia. Setelah periode krisis moneter pada 1990an akhir terjadi, lalu diteruskan dengan adanya kebijakan otonomi daerah, sejak saat itu pamor Jalan Jaksa sebagai sebuah backpacker enclaves terus menurun hingga saat ini. Banyak hunian warga yang awalnya berfungsi sebagai sarana akomodasi bagi para backpacker kemudian kembali mengalami perubahan fungsi akibat berubahnya aktivitas dari penghuni. Semua perubahan tersebut terjadi sesuai dengan apa yang dirumuskan oleh Habraken, 1983 bahwa proses dan produk perubahan pada sebuah kawasan permukiman biasanya ditandai dengan terjadinya perubahan struktur dalam masyarakat dan munculnya penemuan baru akibat pengaruh kontak dengan budaya lain. Keberlangsungan perubahan ini masuk dan berkembang secara perlahan, bahkan mungkin tanpa disadari. Pengaruh kontak dengan budaya lain terjadi saat proses konsumsi dalam sebuah perdagangan berlangsung dan memungkinkan adanya interaksi antara pengunjung dan warga sekitar atau pengelola sebuah fasilitas wisata (Edensor, 1998).

Ruang fisik atau spasial sebagai tempat di mana kegiatan interaksi tersebut berlangsung pada akhirnya dapat dijadikan sebagai representasi bagaimana transformasi di sebuah kawasan terjadi. Maka dari itu, pada penelitian ini istilah spasial yang dimaksud dapat diartikan sebagai ruang geometri tiga dimensional yang menjadi tempat penduduk dan pengunjung melakukan kegiatan sehari-hari. Pada kasus ini, proses transformasi terjadi karena adanya supply-demand berupa kebutuhan pengunjung dan respon masyarakat lokal. Adanya banyak pengunjung dengan motif kedatangan yang berbedabeda sebagai sebuah proses tidak hanya dapat menghasilkan perubahan tata ruang hunian atau spasial sebuah kawasan secara arsitektural menjadi komersil, tapi juga berimbas pada perekonomian yang akan berpengaruh pada perilaku dan pola hidup masyarakat daerah tersebut. Salah satunya dengan cara menimbulkan mata pencaharian baru sebagai bentuk respons masyarakat sekitar terhadap kebutuhan tren pengunjung.

Selain itu, dapat pula menjadi tempat masuknya budaya luar yang dibawa pengunjung saat datang maupun menetap di suatu kawasan. Hal-hal di atas menggambarkan adanya dinamika transformasi pada kawasan yang telah memiliki kesan sebagai sebuah backpacker enclaves sejak lama hingga akhirnya citra tersebut luntur. Saat ini kawasan tersebut mulai kehilangan citranya karena adanya perubahan mayoritas jenis pengunjung. Maka melihat pada proses dan dampak fenomena lahirnya transformasi di sebuah kawasan akibat adanya interaksi antara warga dan pengunjung yang datang, Ini menjadi menarik untuk diteliti dan dikaitkan dengan ilmu Arsitektur. Karena dampak transformasi tersebut dapat berpengaruh ke banyak aspek lainnya di kehidupan masyarakat. Fenomena perubahan lingkungan sekitar akibat jenis pengunjung yang datang dinilai layak untuk dijadikan sebuah bahan penelitian. Riset yang dilakukan sebagai sebuah latihan akademis ini, diharapkan dapat menghasilkan pengetahuan baru terkait transformasi hunian di Jalan Jaksa. Informasi yang terkumpul juga diharapkan dapat menjadi rekomendasi bagi pihak terkait (misal pemerintah daerah) untuk memantau jalannya perubahan yang terjadi pada kawasan ini agar menjadi lebih terarah dan berkesinambungan. 


\section{Bahan dan Metode}

Penelitian ini merupakan penelitian mengenai transformasi spasial karena pengaruh kegiatan pariwisata. Konsep besar dari penelitian ini adalah teori supply-demand pariwisata, diterjemahkan sebagai kebutuhan pengunjung yang disambut warga sekitar menjadi sebuah wadah usaha komersil. Bangunan yang diamati bersifat permanen dan temporal, sesuai dengan indikasi adanya perubahan terhadap guna bangunan dari fungsi hunian menjadi fungsi lain.

Metode yang dipakai adalah metode kualitatif (Creswell, 2002) dengan setting waktu cross-sectional studi. Pada tahap awal penelitian, analisis dilakukan dengan menelaah citra satelit dari google earth Jalan Jaksa periode 2002-2014. Setelah mendapatkan data berupa titik perubahan hunian, dilakukan observasi secara langsung selama satu minggu pada hari kerja (low season) dan akhir pekan (peak season) baik saat siang dan malam hari. Tujuannya adalah untuk membandingkan keadaan hunian dengan asumsi adanya perbedaan supply dan demand pada waktu low season dan peak season. Adapun metode pengumpulan data yang dilakukan pada penelitian ini dibagi menjadi dua yaitu penelitian kepustakaan (secondary sources/ pengumpulan data sekunder) berupa telaah dokumen seperti hasil analisis biro pusat statistik, data hasil penelitian sebelumnya yang telah dilakukan oleh akademisi dalam bentuk teori, jurnal ilmiah serta artikel. Serta penelitian lapangan (primary sources/ pengumpulan data primer) dengan cara observasi dan wawancara. Pada tahap observasi lapangan peneliti menempatkan dirinya sebagai non-participant (Kumar, 2015). Hal yang dilakukan diantaranya adalah menyusuri lokasi studi kasus untuk kemudian dilakukan pemetaan sesuai dengan perbedaan karakteristik jalan, dan batas-batas daerah setiap Rukun Warga. Tujuannya adalah untuk menghasilkan pemetaan studi kasus berdasarkan wilayah, agar dapat menentukan hunian mana yang akan dijadikan objek studi kasus. Adapun dari hasil pemetaan ini didapat 26 buah hunian yang berada di Jalan Jaksa sebagai studi kasus.

Selanjutnya peneliti melakukan wawancara terstruktur kepada pemilik, dan pengelola hunian sebagai pemangku kebijakan. Wawancara dilakukan dengan pedoman pertanyaan yang sifatnya terbuka (open-ended interview) dengan membuat daftar pertanyaan kunci yang telah disesuaikan dengan rancangan variable. Adapun variabel bebas dalam penelitian ini dibagi kedalam dua buah konsep besar yang disesuaikan dengan penjelasan di atas yaitu pengunjung (demand) dan pemilik, pengelola serta penentu kebijakan (supply). Dari masing-masing konsep tersebut dibagi lagi kedalam beberapa atribut variabel. Variabel dari konsep pengunjung meliputi karakteristik, aktivitas serta ideologi. Sedangkan konsep pemilik, pengelola dan penentu kebijakan dibagi menjadi variabel posisi, familiaritas, kebijakan serta kontrol. Sedangkan variabel terikat dalam penelitian ini adalah: konsep transformasi spasial hunian. Konsep tersebut dibagi kedalam variabel fungsi ruang, fasad bangunan dan koridor.

Hasil wawancara melahirkan informasi-informasi berupa cerita dan pengalaman dari stakeholders dan actors selama berada dan terlibat dalam proses transformasi spasial di Jalan Jaksa dan sekitarnya. Metode pengambilan sampel wawancara dipilih menggunakan tipe non-random atau probability sampel (Kumar,2005) dan dilakukan total kepada 66 orang yang memiliki peran berbeda pada hunian yang bertarnsformasi. Teknik ini memungkinkan setiap populasi memiliki peluang yang sama untuk dijadikan anggota sampel. Tujuannya agar didapat kesimpulan terkait sejauh mana individu tersebut berperan dalam proses transformasi. Selain itu, agar didapat pula data mengenai produk transformasi spasial yaitu perubahan yang sudah terjadi di masing-masing hunian atau jenis usaha sesuai dengan apa yang individu tersebut lakukan sehingga dapat dikategorikan setiap jenis sampelnya sesuai dengan perubahan fungsi bangunannya.

Setelah transformasi hunian dijelaskan secara deskriptif dan ditambahkan dengan data dokumentasi foto, selanjutnya transformasi hunian dianalisis dengan cara melihat 
tingkat adaptif perubahan huniannya. Tahapan ini bertujuan untuk melihat seberapa besar transformasi terjadi, dan sejauh mana hunian berubah dari bentuk awal serta kemungkinannya untuk dapat berubah kembali menjadi bentuk sebelumnya. Penilaian dilakukan dengan memberikan ranking atau peringkat 1-12 pada tiap-tiap hunian yang menjadi studi kasus. Besarnya tingkatan rangking memiliki fungsi untuk menjelaskan tingkatan transformasi. Tingkatan transformasi ini kemudian dibagi kedalam tiga tingkatan, yaitu installation diberi nilai 1-4, insertion diberi nilai 5-8, dan intervention diberi nilai 9-12 sesuai dengan penilaian White, 1999 dalam Park, 2009 dalam Gewirtzman, 2016. Penelitian ini mengadopsi penilaian tersebut namun dengan menambahkan detail warna pada setiap peringkatnya menjadi komposisi gambar di bawah ini (Gambar 1):

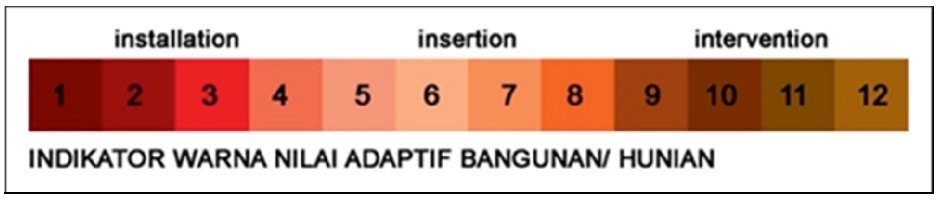

Gambar 1. Detail Indikator Warna Nilai Adaptif Hunian (Sumber: Analisis Pribadi, 2017)

Gambar 1 di atas menjelaskan bahwa pewarnaan bertujuan untuk memperlihatkan sampel mana yang mengalami installation, yaitu keadaan dimana bangunan baru dan lama berdiri secara terpisah dan jika bangunan baru dibongkar maka bangunan lama kembali menjadi bentuk semula (rangking 1-4), insertion yaitu keadaan menempatkan sebuah bagian baru yang memiliki elemen sesuai dengan selubung bangunan lama dan ditempatkan pada bangunan lama (ranking 5-8) dan intervention yaitu bangunan lama mengalami transformasi yang masif sehingga tidak lagi berdiri utuh, dan bagian baru serta bagian lama bangunan terintegrasi (ranking 9-12).

\section{Hasil dan Diskusi}

Bab ini menguraikan hasil analisis dari data yang didapat saat melakukan studi lapangan berupa observasi lanjutan dan wawancara sebagai penyempurna data studi literatur dan observasi awal. Hasil analisis berisi penjelasan deskriptif dan interpretasi dari data kualitatif yang didapat. Interpretasi berupa rangkaian analisis deskriptif tersebut dibuat untuk menjawab pertanyaan penelitian, yaitu sejauh mana transformasi spasial telah terjadi pada hunian di Jalan Jaksa, Jakarta Pusat.

\subsection{Elemen Wisata Kawasan Jalan Jaksa}

Sub-bab ini akan menjelaskan aspek komponen pariwisata yang ada di Jalan Jaksa dari segi penawaran (supply) secara deskripsi dari hasil wawancara dan observasi lapangan. Poin-poin yang dibahas merupakann aplikasi dari teori Gunn (1988) yang menyatakan bahwa komponen penawaran (supply) pada sebuah kegiatan pariwisata terdiri dari aspek atraksi atau daya tarik, aspek aksesibilitas, aspek amenitas (fasilitas penunjang) dan aspek aktivitas. Tujuan dibahasnya aspek penawaran ini adalah agar diketahui apa saja hal-hal yang menjadi kelebihan dan kekurangan dari kawasan Jalan Jaksa saat ini jika dilihat dari segi penawaran (supply) tersebut.

\subsubsection{Aspek Atraksi atau Daya Tarik}

Daya tarik (atraksi) wisata di kawasan Jalan Jaksa adalah kekerabatan warga yang pada akhirnya menghasilkan berbagai jenis wisata kota yang tersedia. Jalan Jaksa merupakan sebuah kawasan kampung kota di mana letaknya berada dekat dengan pusat 
keramaian ibukota dan pemerintahan, namun warga lokalnya masih hidup secara berdampingan satu sama lain. Rasa saling pengertian antar masyarakat tesebut menjadi alasan terbentunya organisasi dalam menjalankan bisnis seperti Ikatan Usaha Kepariwisataan Jalan Jaksa (IKJS) dan Ikatan Pemuda Jalan Jaksa. Menurut Baskoro (2010) Jalan Jaksa dapat dikategorikan sebagai wisata berbasis komunitas. Kearifan warga lokal tersebutlah yang menurut Helmy Zainy, selaku sekretaris dari IKJS yang juga seorang warga lokal merupakan kunci awal bagaimana para wisatawan tertarik untuk datang. Selain sebagai sebuah kawasan yang menyediakan sarana akomodasi dengan harga terjangkau namun mencoba memberikan pelayanan terbaik, Jalan Jaksa dikenal oleh para backpacker pada jamannya karena cara hidup warga nya yang mereka nilai menarik.

Intinya, kemampuan warga menerima sebuah kultur baru yang dibawa masuk oleh wisatawan dengan tangan terbuka namun tetap dapat bertahan dalam norma-norma yang diusung masyarakat lokal adalah kunci awal daya tarik wisata Jalan Jaksa muncul. Kemampuan tersebutlah yang membuat kawasan ini berkembang dari sebuah kampung kota biasa menjadi kawasan pariwisata yang memiliki berbagai jenis sarana pemenuh kebutuhan yang membuat banyak pengunjung datang. Kawasan ini memungkinkan pengunjung untuk melakukan banyak kegiatan rekreasi seperti wisata kuliner (makan, minum), hiburan (karaoke, kolam renang, biliar), dan juga beristirahat setelahnya pada sebuah tempat yang saling berdekatan dengan harga yang lebih terjangkau jika dibandingkan tempat lain yang menawarkan jenis wisata yang sama. Terutama setelah resmi menjadi sebuah Kawasan Wisata Malam. Selain itu, sebagai sebuah Kawasan pariwisata Jalan Jaksa juga memiliki kegiatan tahunan yang tidak semua kawasan wisata miliki yaitu Festival Jalan Jaksa. Festival ini dijadikan sebagai salah satu rangkaian acara perayaan Hari Ulang Tahun DKI Jakarta dianggap masih menjadi daya tarik tersendiri bagi pengunjung untuk mendatangi Kawasan Jalan Jaksa seperti dilaporkan berbagai macam media.

\subsubsection{Aspek Aksesibilitas}

Keberadaan Kawasan Jalan Jaksa yang berada didekat pusat ibukota dan pemerintahan merupakan nilai jual utama karena akses yang tersedia dari dan ke Jalan Jaksa sangat beragam dan mudah. Keterjangkauan dalam segi aksesibilitas tersebut secara umum membuat banyaknya pengunjung memilih tinggal karena Jalan Jaksa memungkinkan mereka untuk tidak hanya tinggal dan menghabiskan waktu di sarana akomodasinya namun juga dapat mendatangi berbagai macam tempat wisata unggulan di Jakarta dalam jarak yang masih terbilang dekat dengan berbagai macam pilihan transportasi. Selain aksesibilitas dengan daerah sekitarnya, aksesibilitas di sekitar Jalan Jaksa juga dinilai cukup baik. Sebagai jalan satu arah, lebar jalan cukup besar, yaitu sekitar enam meter dan dapat dilalui dengan berbagai jenis kendaraan baik itu kendaraan roda dua seperti mobil maupun roda empat seperti motor dan sepeda, bahkan kendaraan besar seperti truk pun sering melewati jalan ini. Adapun keberadaan trotoar di kiri dan kanan jalan utama dengan lebaran yang cukup luas sekitar satu setengah hingga dua meter juga dapat dijadikan sebagai nilai tambah. Koridor berupa trotoar tersebut dapat digunakan pejalan kaki untuk berjalan dengan aman dan juga untuk PKL berjualan. Terdapat pula jaringan jalan yang menghubungkan Jalan Jaksa dengan jalan lain disekitarnya.

\subsubsection{Aspek Amenitas atau Fasilitas Penunjang}

Fasilitas penunjang (amenitas) dalam kegiatan pariwisata dapat meliputi keberadaan akomodasi, pusat informasi, toko cinderamata, pusat kesehatan, sarana komunikasi, keamanan, dan ketersediaan sarana umum (toilet, masjid). Di Jalan Jaksa sarana akomodasi yang ada bersifat penginapan bertarif murah, sama seperti image nya 
sebagai sebuah backpacker enclaves. Hingga saat ini, penginapan yang menamakan dirinya wisma, hostel dan homestay keberadaannya masih cukup banyak. Selain itu, terdapat pula hotel budget yang sejak lama telah berdiri maupun yang baru terbangun. Selain akomodasi, di sepanjang Jalan Jaksa juga terdapat berbagai jenis tempat makan mulai dari PKL, warung nasi, kedai, restoran keluarga, kafe hingga $p u b$ dan bar sebagai pilihan. Sarana penunjang lain seperti toko kelontong, minimarket, stan buku, salon kecantikan, binatu, warung internet, jasa fotokopi, toko baju, agensi travel, tempat penukaran uang semuanya pun masih ada dan bertempat di Kawasan Jalan Jaksa sayangnya kebanyakan memiliki kualitas yang tidak begitu baik. Para pemilik dan pengelola usaha hanya menjalankan usaha dengan seadanya dan bertahan dari hari ke hari dengan biaya minimal dari keuntungan yang telah didapat dan hal ini telah berjalan selama bertahun-tahun dimulai dari krisis 1997-98. Menurut Helmy Zainy, keuntungan yang tidak seberapa tersebut menyebabkan pihak pemilik dan pengelola usaha tidak memiliki kemampuan untuk memperbaiki desain maupun kualitas pelayanan yang ada.

\subsection{Aspek Aktivitas}

Aspek aktivitas yang berlangsung saat kegiatan wisata meliputi aktivitas rekreasi atau hiburan dan aktivitas usaha. Aktivitas rekreasi meliputi berbagai macam kegiatankegiatan terutama yang berhubungan dengan penetapan Kawasan Jalan Jaksa sebagai Kawasan Wisata Malam diantaranya kuliner dan hiburan malam. Aktivitas rekreasi tersebut dilaksanakan di seluruh penjuru kawasan terutama di sepanjang koridor trotoar dan di dalam tempat-tempat hiburan yang dituju berada. Aktivitas dapat berlangsung setiap hari selama tempat penunjang yang berupa sarana wisata menjalankan usahanya. Sedangkan pada aktivitas khusus seperti saat adanya Festival Jalan Jaksa, perayaan Hari Ulang Tahun Indonesia dan kegiatan-kegiatan lain yang melibatkan masyarakat lebih banyak, maka tempat kegiatan aktivitas dipastikan menggunakan ruang yang lebih besar. Biasanya, dalam penyelenggaraan aktivitas khusus tersebut ruang sepanjang jalan seluruhnya akan digunakan hingga menyebabkan penutupan bagi kendaraan bermotor agar masyarakat dapat menikmati aktivitas dengan aman dan nyaman. Selain aktivitas rekreasi, adapula aktivitas usaha yang berlangsung di Kawasan Jalan Jaksa. Aktivitas usaha tersebut meliputi penjualan barang dan jasa. Penjualan jasa diakomodasi oleh usaha-usaha seperti agen akomodasi penginapan, travel, binatu, salon kecantikan, dan warung internet. Selain itu ada pula jasa yang diberikan oleh orang-orang yang memiliki keahlian diantaranya jasa pembantu mencari penginapan dan jasa pemandu wisata (tour guide) yang tersebar di berbagai penjuru Jalan Jaksa.

\subsection{Transformasi Spasial Pada Hunian}

Dari hasil observasi sekunder dan primer yang telah diamati sesuai dengan variabel yang ditetapkan, maka dapat disimpulkan bahwa Jalan Jaksa dan sekitarnya disinyalir mengalami adanya transformasi spasial di berbagai titik dengan skala yang beragam, mulai dari kecil (renovasi hunian) hingga skala lebih besar (pemugaran lebih dari satu hunian kemudian dijadikan atau dalam tahap pembangunan menjadi bangunan baru). Adapun hasil analisis tersebut dapat dilihat pada Gambar 2 di bawah ini: 


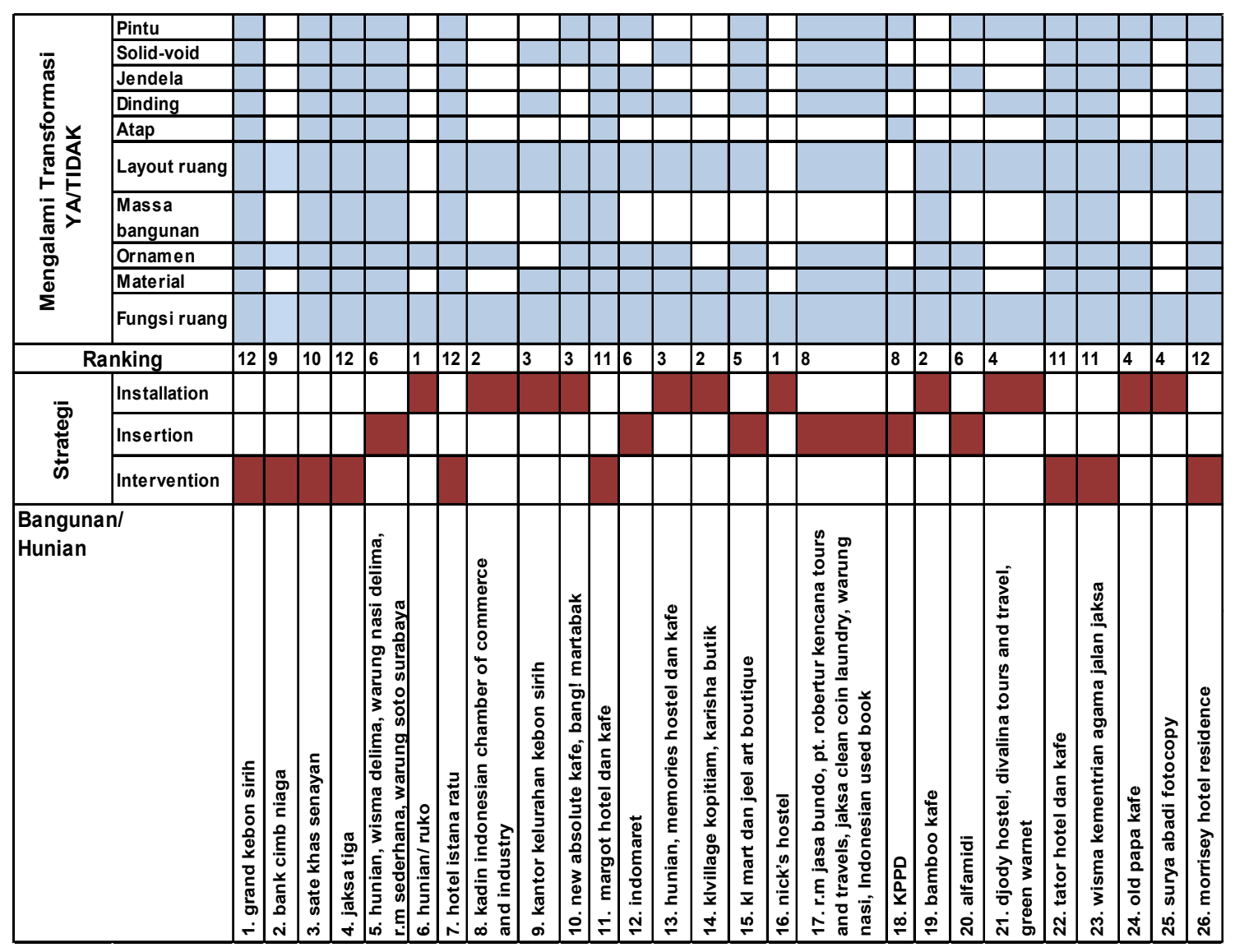

Gambar 2. Hasil pemetaan strategi transformasi dan nilai intervensi pada tiap-tiap sampel hunian di Area 1 berdasarkan modifikasi dari tabel kategori Brookner dan Stone (2004)

(Sumber: Analisis Pribadi, 2017)

Hasil analisis menunjukan pada sampel penelitian (Gambar 2), dari 26 jumlah sampel terdapat 12 sampel bangunan/hunian (46.1\%) yang mengalami installation, berarti sifat bangunannya adaptif, lima sampel bangunan/hunian (19.2\%) mengalami insertion, keadaan bangunan dinilai cukup adaptif serta sembilan bangunan/hunian (34\%) mengalami intervention berarti keadaan bangunan tidak adaptif. mayoritas bangunan mengalami strategi installations atau beranking 1-4 artinya bersifat adaptif. Bangunan yang memiliki predikat sifat bagunan adaptif kebanyakan merupakan bangunan yang masih berfungsi sebagai hunian namun kemudian berubah fungsi menjadi bangunan mixused, biasanya mengakomodasi usaha retail barang (seperti restoran, kafe, kedai dan lainlain) dengan cara disewakan pada orang lain maupun dipakai berdagang secara langsung oleh pemilik bangunan seperti pada sampel 5, 10, 13, dan 16. Bangunan dengan tipe mixused ini memungkinkan pemilik/penyewa usaha berganti dengan cepat dalam berbisnis dan melakukan perubahan pada ruangnya sesuai dengan kebutuhan. Arah perubahan dan adaptifitas bangunan sangat tergantung pada peran pemegang kontrol saat melakukan renovasi. Hasil analisis saat melakukan wawancara menemukan fakta bahwa hampir $100 \%$ perubahan yang terjadi adalah kontrol dari pemilik. Tidak banyak disebutkan peran arsitek/desainer pada perubahan bangunan selain yang terjadi pada gedung-gedung dengan skala besar seperti studi kasus nomor 1, 4 dan 26 pada sampel penelitian. Kebanyakan pemilik merubah huniannya dengan cara merencanakan nya secara mandiri dan kemudian hanya memanggil pekerja yang dirasa kompeten pada bidangnya untuk membangun.

Tingkat adaptif bangunan banyak berada di warna no. 1-4 dan 9-12. Hal ini dapat menjelaskan keadaan dimana perubahan bentukan fisik fasad studi kasus penelitian 
kebanyakan berubah dengan adanya installation, yaitu keadaan dimana bangunan baru dan lama berdiri secara terpisah, jika bangunan baru dibongkar maka bangunan lama kembali menjadi bentuk semula. Terjadi perubahan pada denah atau floor plan dan sosok bangunan/ fasad namun kebanyakan masih memiliki tinggi dan luasan bangunan yang sama. Selain itu, untuk yang mengalami intervention, yaitu keadaan dimana bangunan lama mengalami transformasi yang masif sehingga tidak lagi berdiri utuh, dan bagian baru serta bagian lama bangunan terintegrasi pada area ini kebanyakan berubah menjadi perkantoran dan hotel mewah yang merubah beberapa hingga puluhan unit hunian menjadi sebuah bangunan baru dengan denah ruang, sosok bangunan dan koridor yang berbeda dari sebelumnya sehingga sifat bangunan menjadi tidak adaptif.

Sejalan dengan teori Leseau (1980) yang menjelaskan secara lebih lanjut bahwa transformasi memiliki empat jenis sifat perubahan yaitu topologikal (geometri), dimana terjadi perubahan terhadap bentuk geometri namun tetap memiliki komponen pembentuk serta fungsi ruang yang sama. Selanjutnya gramatika hiasan (ornamental), perubahan terjadi dengan cara menggeser, memutar, mencerminkan, menjungkirbalikan serta melipat sebuah objek. Selain itu, sifat yang ketiga adalah reversal (kebalikan), yaitu keadaan di mana sebuah citra yang ada kemudian dirubah menjadi citra sebaliknya dan yang terakhir distortion (merancukan), yaitu keadaan dimana perubahan yang terjadi dibebaskan arahnya tergantung pada perancang dan aktivitas kreatifnya. Strategi installation biasanya sejalan dengan perubahan geometri, insertion sejalan dengan ornamental dan reversal serta intervention merupakan cerminan dari perubahan secara distortion.

\subsection{Kategorisasi Perubahan Spasial Berdasarkan Fungsi Bangunan}

Sub-bab ini menjelaskan sejauh mana transformasi spasial hunian terjadi pada setiap studi kasus. Adapun tren perubahannya dapat dilihat pada Gambar 3 di bawah ini:

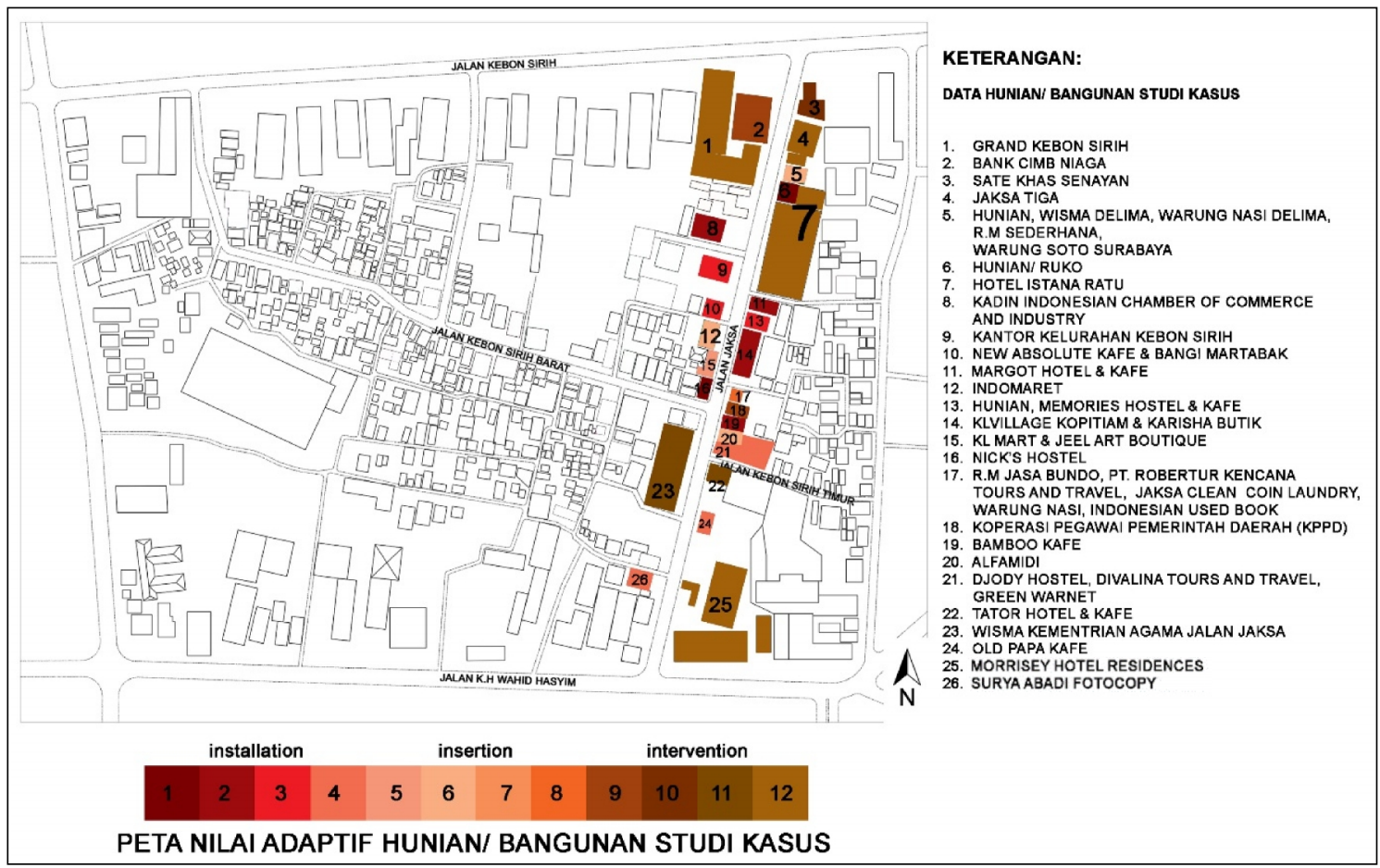

Gambar 3. Peta Nilai Adaptif Hunian Studi Kasus (Sumber: Analisis Pribadi, 2017) 


\subsubsection{Transformasi Hunian Menjadi Gedung Tinggi (Intervention)}

Dari data di atas, dapat disimpulkan bahwa transformasi yang terjadi pada hunian yang kemudian berubah menjadi gedung tinggi mengalami perubahan dengan cara menyatukan beberapa hunian lalu merenovasinya dengan membangun ulang lahan yang telah diratakan menjadi sebuah gedung perkantoran megah. Perubahan yang terjadi pada bangunan mencakup perubahan fasad, dan terkadang koridor dari bangunan tersebut. Fungsi dari pengembangan vertikal sendiri bertujuan untuk efisiensi lahan. Transformasi akibat renovasi vertikal ini juga memberikan dampak berupa kesan yang berbeda terhadap bangunan. Desain bangunan baru yang di telah renovasi kebanyakan berubah menjadi bangunan dengan desain lebih modern dengan pemilihan material yang berbeda dengan hunian di sekitarnya. Transformasi pada tipe ini terjadi secara vertikal dan juga horisontal secara bersamaan. Adapun transformasi yang terjadi meliputi perubahan tata letak perabot, fungsi ruang, fasad dan juga koridor. Hal ini menjadikan hunian mengalami perubahan secara distortion/ merancukan seperti teori Leseau, 1980. Adapun jumlah hunian menjadi Gedung tinggi adalah sebanyak 7 bangunan dari total 26 sampel (26.9\%).

\subsubsection{Transformasi Hunian Menjadi Penginapan}

Spesifikasi penginapan yang didapat dari hasil observasi kebanyakan merupakan penginapan yang telah lama keberadaannya. Hostel dan hotel tersebut merupakan usahausaha warga sekitar yang dijalankan secara turun-temurun sekitar dua generasi dari tahun 1970an. Dari sampel yang didapat, terlihat adanya perkembangan dimana pada saat awal pembentukan (diwakili oleh sampel hostel yang masih eksis dan sudah ada sejak awal wisata backpacker di Jalan Jaksa berkembang) hostel-hostel tersebut awalnya memiliki tipologi horisontal. Kebanyakan bersatu dengan rumah tinggal, dan hanya sekedar melakukan perubahan menambah kamar (penambahan) fungsi ruang. Selain jenis penginapan seperti itu, terdapat juga hotel-hotel kelas melati yang telah beroperasi cukup lama dan cenderung memiliki tipologi sama seperti hostel awal, horisontal dan memiliki tinggi maksimal 4 lantai sesuai dengan peraturan pemerintah yang berlaku. Pada tipe perubahan ini ada jenis transformasi yang terjadi, yaitu secara topologikal (geometri) bagi penginapan dengan perubahan installation sebanyak 6 hunian dari 26 sampel (23\%).

Semenjak tidak tegasnya peraturan untuk pembatasan pembangunan gedung maksimal 4 lantai di sekitar Jalan Jaksa di tahun 2000an ada beberapa hotel yang saat ini sudah terbangun maupun masih dalam tahap pembangunan. Dengan adanya pembangunan hotel tersebut, warga dan pengelola hostel lama merasa cukup keberatan karena menurut mereka, hal itu melanggar peraturan dan pihaknya bingung mengapa perizinan pembangunan dapat keluar. Banyak warga yang merasa tempat tinggalnya tidak lagi nyaman dikarenakan hal tersebut. terjadi saat ini. Untuk perubahan huniannya sendiri, tipe hotel ini melakukan akuisisi lebih dari tiga bangunan, lalu merenovasi secara total dan merubah lahan tersebut menjadi sebuah gedung bertingkat banyak (mirip seperti yang terjadi pada Transformasi Kategori Perkantoran) hanya saja, peruntukan bangunannya adalah sebagai hotel. Jenis perubahan tipe ini termasuk ke dalam perubahan intervention, merupakan cerminan dari perubahan secara distortion. Jenis penginapan dengan perubahan tipe ini berjumlah 4 bangunan dari 26 sampel (15\%).

\subsubsection{Transformasi Hunian Menjadi Mix-used Building}

Jenis retail barang didominasi oleh kafe, kedai dan restoran yang memiliki fungsi sebagai tempat berkumpulnya pengunjung untuk melakukan kegiatan makan, minum, nongkrong maupun bertemu dan berinteraksi dengan sesamanya. Jumlah sampel retail barang ini mencapai $80 \%$ dari total sampel yang ada. Pada umumnya, beberapa kafe merupakan bisnis yang menyatu (berada dalam satu gedung) dengan penginapan, dan 
hunian pemilik. Tipe seperti ini kebanyakan merupakan kafe yang telah berdiri sejak lama di era masa keemasan Jalan Jaksa sekitar tahun 1980-90an. Transformasi spasial yang pemilik dan pengelola lakukan rata-rata adalah dengan merubah halaman depan dan teras hunian yang mereka miliki menjadi sebuah kafe. Jadi, kebanyakan kafe di Jalan Jaksa bersifat semi-outdoor dengan dinding partisi yang tidak masif menggunakan material yang terlihat natural seperti anyaman bambu.

Tujuan dari desain tersebut menurut pemilik dan pengelola adalah agar target pengunjung yang pada awal pendirian usaha merupakan para backpacker asing, dapat merasakan suasana yang berbeda dengan daerah asal mereka. pemilik dan pengelola menilai, backpacker lebih menyukai suasana yang natural dan terlihat sangat Indonesia sehingga pada akhirnya desain tersebut dipilih. Selain desain di atas, terdapat juga sarana penunjang yang menempati sebuah bangunan rumah secara utuh. Usaha retail barang atau jasa jenis ini menempati bangunan secara keseluruhan, merubah atau merenovasi fungsi ruang yang ada disesuaikan dengan kebutuhannya dengan menambahkan signage, dan lainnya (contoh indomaret). Namun, seiring berjalannya waktu dan terjadi sedikit perubahan, saat ini lebih banyak terdapat restoran maupun kedai yang bukan lagi memiliki target utama pengunjung backpacker. Kedai dan restoran ini kebanyakan muncul di akhir tahun 2000an dan memiliki tujuan untuk menjadi pilihan wisatawan lokal, yaitu anak muda yang berasal dari daerah sekitar Jakarta untuk makan dan nongkrong. Selain itu, banyak pula kedai-kedai makanan berukuran kecil yang membuka usahanya serta memiliki tujuan untuk mengambil pasar karyawan. Transformasi yang terjadi kebanyakan berada pada jenis insertion di mana hunian mengalami transformasi secara ornamental dan reversal. Dari 26 sampel, yang mengalami terdapat 13 sampel yang mengalami perubahan jenis ini (50\%).

Akibat adanya pergeseran tersebut, daerah Jalan Jaksa dan sekitarnya saat ini tidak lagi semarak dengan signage dan lampu-lampu. Desain yang ada menjadi lebih practical atau hanya mementingkan kebutuhan dan fungsi utama juga minim dari kesan dekoratif. Kebanyakan malah tidak memiliki desain sama sekali, sehingga penampakan koridor di kawasan Jalan Jaksa terlihat sepi jika dibandingkan dengan dokumentasi keadaan Jalan Jaksa pada era 1980 akhir hingga awal 1990an. Para pengelola dan pemilik banyak mengeluhkan turunnya jumlah pengunjung semenjak jatuhnya ekonomi pada tahun 1998. Hal ini berakibat pada omset yang dihasilkan dimana saat ini, banyak usaha-usaha kafe yang hanya mampu untuk menutupi kebutuhan operasional sehari-hari hingga pada akhirnya renovasi dan pembaharuan desain tidak dilakukan. Transformasi yang terjadi pada hunian secara fisik dapat sangat terlihat pada fasad bangunan. Sebuah bangunan, saat telah berubah fungsi menjadi mix-used biasanya memiliki lebih dari satu pintu utama dan terlihat memiliki fasad bangunan yang berbeda antara satu sama lainnya sehingga membentuk kesan berdiri pada bangunan/ hunian yang berbeda walaupun sebenarnya masih berada dalam sebuah kesatuan. Selain itu terdapat pula jenis perubahan lain di mana pada jenis ini, perubahan bangunan terjadi dengan adanya penambahan bangunan kecil baru (seperti pavilion) di area sekitar teritori hunian.

\section{Simpulan}

Transformasi spasial pada hunian di Jalan Jaksa terjadi karena adanya kecermatan warga menangkap peluang usaha dari banyaknya pengunjung yang datang. Cara masyarakat sekitar melakukannya adalah dengan merubah huniannya menjadi sebuah bentuk usaha yang menurut mereka dapat menghasilkan keuntungan. Perubahan fungsi ruang dapat dilihat dari adanya beberapa kepentingan dan perbedaan pemakai dalam sebuah hunian atau bangunan di mana pada kasus Kawasan Jalan Jaksa, banyak hunian dengan perubahan berbeda-beda menyebabkan kemungkinan perubahan fungsi ruang, fasad bangunan dan koridor yang berbeda-beda pula. Perubahan fungsi ruang secara 
permanen akan terjadi disaat fungsi ruang lama dinilai tidak dapat lagi memenuhi kebutuhan aktivitas dari penggunanya sedangkan secara temporal ruang yang mengalami perubahan fungsi dapat kembali berubah menjadi fungsi awalnya sehari-hari. Kondisi adanya perubahan ruang secara temporal biasanya terjadi pada waktu-waktu khusus. Misalnya pada kondisi peak season. Dalam melakukan perubahan secara permanen, dilakukan usaha renovasi untuk pembentukannya. Dari banyaknya renovasi yang telah dilakukan, dapat disimpulkan kategori perubahan terdiri dari transformasi spasial hunian menjadi Gedung tinggi, penginapan, dan mixed use building. Metode analisis data yang digunakan peneliti sangat sederhana sehingga dalam penemuan informasi, interpretasinya masih dangkal. Dimungkinkan bagi penelitian selanjutnya untuk menggunakan berbagai macam metode analisis data yang lebih kompleks agar hasil analisis yang didapatkan menjadi lebih baik.

\section{Ucapan Terima Kasih}

Terimakasih untuk warga Jalan Jaksa yang telah berpartisipasi sebagai narasumber dalam penelitian ini.

\section{Daftar Pustaka}

Baskoro, B. (2010). Wisata Kota Jalan Jaksa: Sebuah Kajian Sosiologi Pariwisata. Depok, Penerbit Koekoesan.

Creswell, J. W. (2002). Research Design: Qualitative, Quantitative, And Mixed Methods Approaches. Second edition, Sage Publications, International Education and Professional Pubisher.

Gewirtzman, D.F. (2016). Adaptive Reuse Architecture Documentation Analysis. Journal of Architectural Engineering Technology, Volume 5 Issues 3.

Gunn, C.A. (1988). Tourism Planning (2 ${ }^{\text {nd }}$ Edition). New York, Taylor and Francis.

Habraken, N.J. (1998). The Structure of The Ordinary: Form and Control In The Built Environment. The MIT Press, Massachusetts.

Habraken, N. J. (1983). Transformation of The Site. Cambridge, Massachusetts: A Water Press.

Haristianti, Vika., Wiwik Dwi Pertiwi and Widjaja Martokusumo (2016). Pengaruh Wisata Backpacker Terhadap Transformasi Spasial Kawasan Permukiman: Studi Empiris. Jurnal Arsitektur dam Perkotaan "KORIDOR" Vol. 07 No. 02, Juli 2016p.89-95.

Hibrawan, A. (2008). Facade Bangunan-Bangunan Rumah Tinggal Kolonial di Kawasan Perumahan Tjitaroem Plein Bandung, Tesis Institut Teknologi Bandung.

Klaus Westerhausen and Jim Macbeth (2003). Backpacker and Empowered Local Communities: Natural Allies In The Struggle For Sustainability and Local Control?, Tourism Geographies, 5:1, 71-86, DOI: 10.1080/1461668032000034088

Kumar, R. (2005). Research Methodology: A Step By Step Guide for Beginner. London, Sage Publication.

Laseau, Paul (1980). Graphic Thinking for Architects and Designer. Ney York, Van Nostrand Reinhold.

Schulz, C.N. (1984). Genius Loci, Towards a Phenomenology of Architecture, Rizolli International Publication Inc. New York.

Vogt, Jay (1976). Wandering: Youth and Travel Behavior, Annals of Tourism Research, Volume IV, No. 1, September/October 1976, pp. 25-41

Laman Internet

Down and Out in Jalan Jaksa, data diperoleh melalui situs internet: http://www.peterloud.co.uk/indonesia/jalan_jaksa.html. Diunduh pada 10 Mei 2017. 
Fungsi dan Klasifikasi Bangunan Gedung, data diperoleh melalui situs internet: http://konstruksimania.blogspot.co.id/2012/08/fungsi-bangunan-gedung.html.

Diunduh pada 7 Februari 2017.

Jakarta's Backpacker Paradise No Longer So Edenic, data diperoleh melalui situs internet: http://jawawa.id/index.php/newsitem/jakartas-backpacker-paradise-no-longer-soedenic-1447893297. Diunduh pada 7 Februatri 2017.

Jalan Jaksa - The Backpacker Budget Accommodation Street in Jakarta, data diperoleh melalui situs internet: http://www.nomadicnotes.com/travel-blog/jalan-jaksa-thebackpacker-budget-accommodation-street-in-jakarta/. Diunduh pada 7 Februari 2017.

Jalan Jaksa- Kebon Sirih Backpacker Hotel, data diperoleh melalui situs internet: http://horchang.blogspot.co.id/2011/11/jalan-jaksa-kebon-sirih-backpacker.html. Diunduh pada 30 September 2016.

On the Hippie Trail: Going Home, data diperoleh melalui situs internet: http://www.hansroodenburg.nl/trail/goinghome.html. Diunduh pada 30 Agustus 2016.

The Popular and Affordable Jaksa Street Jakarta, data diperoleh melalui situs internet: http://www.vacationbaliindonesia.com/popular-affordable-jaksa-street-jakarta/. Diunduh pada 10 Mei 2017.

The Merry and Illustrated History of The Hippies, data diperoleh melalui situs internet: http://www.coopertoons.com/merryhistory/hippies/hippies.html. Diunduh pada 15 Agustus 2015.

Tourism as a science, data diperoleh melalui situs internet: http://kusumamaya.blogspot.co.id/2008/06/tourism-as-science.html. Diunduh pada 12 Januari 2017.

Warga Kebon Sirih Bersedia Digusur untuk Gedung MNC Jika, data diperoleh melalui situs internet:

http://megapolitan.kompas.com/read/2014/02/12/1147263/Warga.Kebon.Sirih.B ersedia.Digusur.untuk.Gedung.MNC.II.jika. Diunduh pada 10 Mei 2017. 